\title{
Thermal analysis of synovial fluids in different stages of osteoarthritis and after bacterial infections
}

\author{
Árpád Dandé ${ }^{\cdot}$ Béla Kocsis ${ }^{2}$ · Dénes Lőrinczy ${ }^{3}$ (I)
}

Received: 7 August 2019 / Accepted: 19 December 2019 / Published online: 13 January 2020

(c) The Author(s) 2020

\begin{abstract}
The analysis of synovial fluid is an important method in diagnosing and handling septic arthritis. To achieve a quick diagnosis could be a great advantage in the therapy. The differential scanning calorimetry (DSC) proved to be a useful technique in the differential diagnosis of tumors using blood plasma or sera. The aim of this paper is to show up some characteristic thermal parameters in the diagnosis of different grades of arthritis, which are in good agreement with the severity of disease checked by conventional X-ray supported grading. To follow the effect of different bacterial strains, the synovial fluids were inoculated by three types of bacterial strains (with $10^{3}-10^{5} \mathrm{CFU} \mathrm{mL}-1$ concentrations) at $37^{\circ} \mathrm{C}$ and stored trough $24 \mathrm{~h}$. After that, they were denatured in $20-90{ }^{\circ} \mathrm{C}$ temperature range with $0.3 \mathrm{~K} \mathrm{~min}^{-1}$ scanning rate. The change in the maximum denaturation temperature $\left(T_{\mathrm{m}}\right)$ and calorimetric enthalpy $(\Delta H)$ monitored the severity of sepsis and depended on the type of bacteria. The proliferation characteristics of bacteria should be strain specific. The synovial fluid samples inoculated with the most frequently occurring bacteria were monitored in isotherm mode (isoperibol calorimeter) at $37{ }^{\circ} \mathrm{C}$ up to the end of the proliferation. The isoperibolic scans clearly demonstrated specific, concentration-dependent representative curves in case of each bacterium (duration of proliferation, maximum of proliferation rates, etc.). Therefore, thermal analysis of human synovial fluid samples by DSC or isoperibolic calorimetry could be a useful tool in the staging of osteoarthritis and the diagnostics of septic arthritis.
\end{abstract}

Keywords Synovial fluid $\cdot$ Septic arthritis $\cdot$ DSC $\cdot$ Isoperibolic calorimetry $\cdot$ Bacterial strains

\section{Introduction}

In the twentieth century, with the advancement of medical science, the development of biochemical, biophysical, and electronic backgrounds brought new and more modern health care products, drugs, and technologies essential to healing. Parallel to this, in primary care as well as in hospital clinics with advanced clinical background, medical diagnostic devices and advanced surgical equipment have become commonplace in daily practice. Continuous innovation in

Dénes Lőrinczy

denes.lorinczy@aok.pte.hu

1 Department of Traumatology and Hand Surgery, Clinical Center, Medical School, University of Pécs, Ifjúság str. 13, Pecs 7624, Hungary

2 Institute of Medical Microbiology and Immunology, Medical School, University of Pécs, Szigeti út 12, Pecs 7624, Hungary

3 Department of Biophysics, Medical School, University of Pécs, Szigeti str. 12, Pecs 7624, Hungary the use of implants for locomotor surgery and the use of modern surgical techniques in the restorative surgical treatment of musculoskeletal system and in the reconstructive surgery of degenerative joint diseases has shown significant progress. Minimally invasive surgical techniques, despite modern implants and aseptic modern surgical environments, continue to challenge infections around implanted implants. Following the production of Penicillin and its derivatives, bacterial infections in a variety of pathologies with a wide range of formulations have been successfully cured. Despite the initial successes, the Penicillin resistance of Staphylococcus aureus - detected in 1942 in individual hospital strains-increased to $80 \%$ in 2 decades. Following the introduction of methicillin in 1961, methicillin-resistant S. aureus (MRSA) strains [1] have emerged and are found worldwide with the rapid increase in antibiotic resistance. The appearance of microorganisms (bacteria, fungi, viruses) in the musculoskeletal structures, including the joints, can lead to a serious condition that can not only endanger the integrity of the joint and bone but also the patient's life. 
Timely recognition and proper care of the process is a matter of urgency and is one of the most important tasks of professionals in locomotor disorders.

Synovial fluid (SF) analysis (composition testing, microbiological inoculation, etc.) is important for the diagnosis and treatment of septic arthritis. From the point of view of therapy, a procedure faster than microbiological tests would be useful. Differential scanning calorimetry (DSC) is an increasingly widely used test method for various pathologic, traumatologic, and orthopedic cases [2-18]. Typical symptoms of septic arthritis (high pain, swelling, redness, fever, warmer tact) do not always occur. In the absence of an adequate immune response, these may even be partially absent. In many cases, it is the physician who sees the patient for the first time, who should be able to think of the septic process even in the case of hidden symptoms. In addition to laboratory, imaging, and focal tests, puncture of the joint is essential. Cultivation of the SF and the initiation of an empirical and then targeted antibiotic treatment and the resting of the joint are required until the breeding result is reached.

While diagnosis of SF samples is based on isolation of the bacterial species, the patient's antecedents, clinical appearance, laboratory results, and imaging studies are also important. Rapid detection, immediate, aggressive antibiotic therapy, and proper surgical treatment are essential for good prognosis. Even with rapid diagnosis and treatment, there is a high mortality rate [19]. Depending on the clinical picture and the primary diagnostic results, arthroscopic joint drana, lavage, or extended joint exploration, synovectomy, necrectomy, will be considered as part of the emergency procedure. In many cases, delayed surgical intervention [20] involves extensive tissue death (synovia and dying of stabilizing ligament, and softening, detaching, and dying of cartilage surface). Typical clinical signs of infection, radiological changes, elevation of inflammatory markers, and detection of septic bone marrow diseases are already possible at an early stage. In spite of the known diagnostic possibilities, however, practice shows that diagnosis and treatment are often delayed. In many cases, in the absence of bacterial isolation, and in the case of a masked clinical picture, the patient is not treated properly, causing serious damage to the joint, which usually causes permanent lesions. In contrast, gonococcal arthritis is often successfully treated with antibiotic therapy, and the rate of complications is very low, and the prognosis for a complete return to normal joint function is excellent [19,21].

The aim of our recent paper is to map out and evaluate diagnostic procedures for accelerating the detection and treatment of joint, periprosthetic septic inflammatory processes over time. In order to prove the low sensitivity of the traditional microbiological extinctions what we assumed, a retrospective clinical study covering the years 2012-2016 was conducted to assess the reliability of the joint and periprosthetic large-scale microbiological seedings. The goal of our study was to evaluate the healing results of patients undergoing septic joint and periprosthetic processes in our clinic over a period of 5 years, as well as the diagnostic specificity and sensitivity of conventional laboratory and microbiological inoculations. With the permission of the Regional Research Ethics Committee, the denaturing of intact and infected synovial fluid and proliferation of different bacterial strains in the synovial medium were investigated with the help of DSC and isoperibol calorimetry with the introduction of an in vitro test model. In the light of the experimental results of our test model, we examined the benefits and possibilities of transmitting calorimetric procedures into clinical practice.

\section{Materials and methods}

\section{Clinical retrospective survey}

Taking into account the main profiles of the Traumatology and Hand Surgery Clinic of Medical School University Pécs, with the permission of the Regional and Institutional Research and Ethics Committee (case number: 6737), we analyzed the acute and elective hand surgery interventions. We have focused on the relationship between the etiology of the joint or periprosthetic early and late infections registered in the primary big-joint and reconstructive surgical procedures within a 5-year (01.01.2012.-31.12.2016.) retrospective study, as well as the sensitivity of conventional microbiological assays. We have identified the inflammatory processes around septic joints as well as large-joint prosthesis during the comparison of electronic medical records (RTG, CT, MRI, laboratory test results, microbiological inoculations) and surgical description.

\section{Considering factors influencing the composition of synovial fluid}

It is known that diseases that increase SF production may be inflammatory and non-inflammatory of origin. In addition to the general rheumatological classification to be highlighted, the infectious arthritis is caused by the bacteria, virus, or fungus. In the sample collection patients with non-inflammatory SF production as well as traumatic cartilage damage and osteoarthritis treated patients were selected. During the sampling, it was taking into account the Kellgren-Lawrence and modified Kellgren-Lawrence radiological classification systems [22] (Table 1); this way achieved samples were from osteoarthritis patients of varying degrees of severity (Gr-I-IV). 
Table 1 Description of Kellgren-Lawrence and the modified Kellgren-Lawrence classification systems [22]

\begin{tabular}{lll}
\hline Classification & Kellgren-Lawrence & Modified Kellgren-Lawrence \\
\hline Gr-0. & No osteoarthritis lesions & No osteoarthritis lesions \\
Gr-I. & Narrowing of the joint gap is suspected, osteophytic "lip formation" is possible & Osteophyte is questionable \\
Gr-II. & Clear osteophytes and possible narrowing of joint gap & Osteophytes are clearly detected \\
Gr-III. & $\begin{array}{l}\text { Moderate, multiple osteophytes, clear narrowing of joint gap, some sclerosis and } \\
\text { deformity at the bone ends possible }\end{array}$ & Narrowing of the joint gap \\
Gr-IV. & $\begin{array}{c}\text { Large osteophytes, the joint gap is explicit narrowing, severe sclerosis, the bone ends } \\
\text { have determined deformity }\end{array}$ & $\begin{array}{c}\text { Apparent disappearance of the } \\
\text { joint gap ("bone on bone") }\end{array}$ \\
\hline
\end{tabular}

\section{Collection and storage of synovial samples}

Taking into account the ethical guidelines of the 2003 Helsinki Declaration, and with the permission of the Regional and Institutional Research and Ethics Committee (license number: 6737), synovial sampling was performed after the oral information of the patients or their adult age relatives and having their signed consent statements. The study included patients of adult age with acute or chronic knee joint pain (pain, loss of movement, inflammatory joint marks) who had undergone a knee joint hyaluronic acid treatment, surgical arthroscopic intervention (knee mirroring), or implantation a prosthesis for replacement of knee joint surface.

During the conservative treatment or surgical procedure, 2-5 $\mathrm{mL}$ of the SF that can be drained by the physician under sterile conditions during knee puncture was placed in a pre-sterilized sealable native tube of $10 \mathrm{~mL}$ (code: B230 BSM470). The data needed to identify the sample were indicated on the test tube. Just after the processing of synovial samples (centrifugation at $3500 \mathrm{rpm}$ for $15 \mathrm{~min}$ followed by transfer of pure synovia into a sterile test tube) or after a storage at $-70^{\circ} \mathrm{C}$ (in a standardized refrigerator), the samples underwent thermal analytical investigations (denaturation in a DSC or proliferation by isoperibol calorimetry).

\section{Investigation of bacterial strains in clinical practice}

In addition to the necessary radiological and general laboratory diagnosis of patients with suspected septic arthritis, microbiological inoculation, laboratory, biochemical quality composition was determined, possibly obtained under sterile conditions. The microbiological test also investigated the antibiotic sensitivity of isolated pathogens in each case, which gave a final result after 4-5 days. In the case of confirmed joint or prosthesis infection, a broad-spectrum combination antibiotic therapy was initiated within the framework of the pre-surgical preparation, which was modified if necessary in the light of the antibiotic sensitivity of the microbiological results.

\section{Thermal denaturation of synovial samples with different degrees of severity by DSC testing}

After collecting and preparing synovial samples from patients fitting to the selection criteria, thermal denaturation was examined by DSC [23] in case of patients with different severities of disease. Thermal characteristics [maximum denaturation temperature $\left(T_{\mathrm{m}}\right)$ and calorimetric enthalpy $\left.\left(\Delta H_{\text {cal }}\right)\right]$ were monitored by a SETARAM Micro DSC-II calorimeter with $0.3 \mathrm{~K} \mathrm{~min}^{-1}$ scanning rate, in temperature range from 37 to $90{ }^{\circ} \mathrm{C}$. We have used a conventional "batch" vessel ( $\left.V_{\max }=1 \mathrm{~mL}\right)$. After the denaturation of the samples, the calorimetric results were compared for patients with different degrees of severity. Because of a limited number of samples, s.d. was calculated to the average in case when the number of observation was greater than 5 .

\section{Healthy synovial samples inoculated with different bacteria}

In this trial, we used inoculated SF [23], infected by different bacterial strains. Three different types of bacterial strains (Staphylococcus aureus and epidermidis, as well as Escherichia coli) were inoculated in $200 \mu \mathrm{L}$ bouillon to reach the $10^{3}$ or $10^{5} \mathrm{CFU} \mathrm{mL}^{-1}$ (Ec) concentrations. Then, $500 \mu \mathrm{L}$ of aseptic human SF was added and the mixture-before the denaturation-was incubated for $24 \mathrm{~h}$ at $37^{\circ} \mathrm{C}$. The analysis and the evaluation of its parameters were made similarly as above. Normal saline was used as a reference. The reference and sample vessels were equilibrated with a precision of $\pm 0.1 \mathrm{mg}$. This way it was not necessary to do any correction between vessels' heat capacity.

\section{Investigation of bacterial strains with isoperibol calorimeter}

Taking into account the preliminary clinical study and the proven research findings in the literature, a pilot model was developed with the permission of the Regional and Institutional Research and Ethics Committee. We have started to record the proliferation of bacterial strains-that are more 
frequent in clinical practice and sometimes cause serious diagnostic and treatment difficulties-in sterile human SF under isothermal experimental conditions with an isoperibol calorimetry [24].

From the Institute of Medical Microbiology and Immunology of the Medical School University Pécs, we have received bacteria from specific cultures: Staphylococcus aureus ATCC 29213, MRSA (Methicillin-resistant Staphylococcus aureus) \# 4262 (\# means that a pyogen was isolated from a clinical specimen), Staphylococcus epidermidis ATCC 14990, Streptococcus pyogenes NCCP 11610, Escherichia coli ATCC 25922, and Pseudomonas aeruginosa ATCC 27853. The test bacteria were prepared using plates of Mueller-Hinton agar (OXOID Ltd., UK) and subjected to a bacterial suspension in Mueller-Hinton's broth (OXOID Ltd., UK) in $10^{3}$ or $10^{5}$ colony-forming units (CFU). Bacterial suspension of various colony-forming units $\left(10^{3}\right.$ and $\left.10^{5} \mathrm{CFU} \mathrm{mL}^{-1}\right)$ was examined by the photometric method (PerkinElmer photometer $\lambda=600 \mathrm{~nm}, E=0.100$ ) and tested by breeding. From the colony-forming samplesafter setting their concentration $\left(10^{3}\right.$ and $\left.10^{5} \mathrm{CFU} \mathrm{mL} \mathrm{mL}^{-1}\right)$-a sterile dose was placed into the specially designed "mixing batch" vessels, which underwent to an isothermal (isoperibol) program.

\section{Results}

\section{Results of the clinical retrospective survey}

Based on our comprehensive retrospective survey, the summary of more frequent joint and periprosthetic infections is shown in Table 3. We found 137 joint and periprosthetic

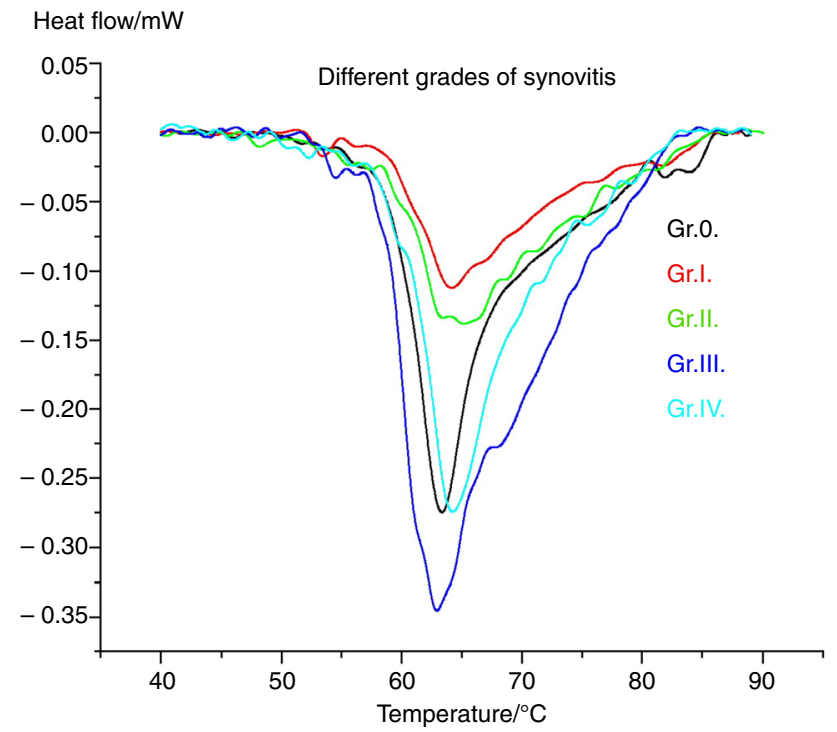

Fig. 2 Thermal denaturation of SF samples at different stages of osteoarthritis. Downward deflections mean endothermic process

infections-during the treatment of the patients-from the microbiological inoculations, based on our overall results. In case of patients treated with infection, we have found $65(47.45 \%)$ hands or feet small-joint and $72(52.55 \%)$ big-joint infections.

Infections of the small joints are mainly caused by external force, injuries, while some of the big-joint infections are due to medical intervention and are one of the early or late complications following big-joint prosthesis surgery $[23,24]$. To test the reliability of conventional microbiological examinations, the performed retrospective

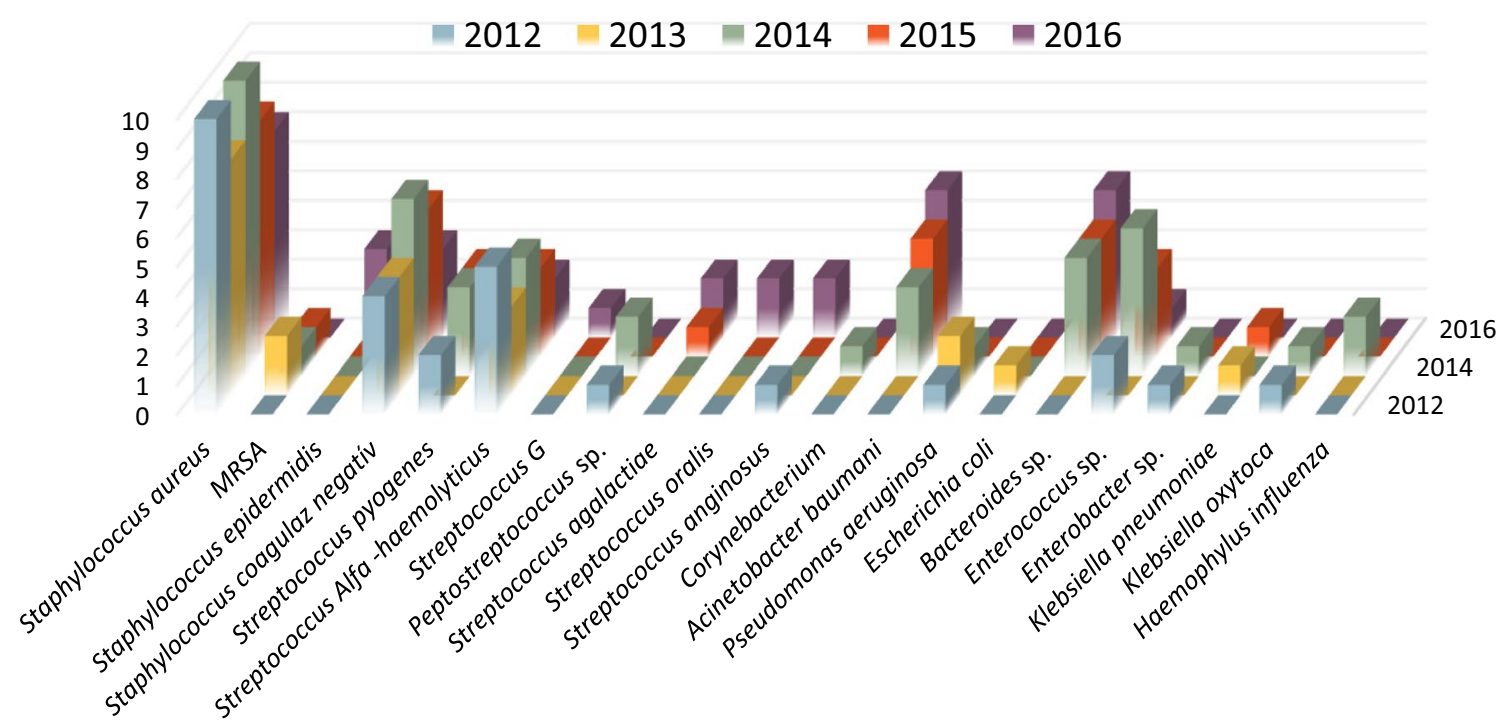

Fig. 1 Distribution of prevalence of bacterial strains 
clinical assessment of 5 years revealed that primary pathogens were not detectable in 30 cases ( 22\%) among 137 joint and periprosthetic confirmed purulence. In the light of the results of primary seedings, various staphylococcus strains lead in the infections: Staphylococcus aureus 43 ( 22\%), Staphylococcus coagulase negative $22(\sim 11 \%)$, Staphylococcus epidermidis $3(\sim 1.5 \%)$, and methicillinresistant Staphylococcus aureus (MRSA) 4 ( 2\%) (see Fig. 1).

Based on the summary of the examined case numbers, more than half of the primary implanted hip replacement prostheses at our clinic are preceded by a femoral fracture condition. In most cases-at post-fracture hip replacement prosthesis implantation-hemopoietic prosthesis (HEP) implantation is adapted to the needs of patients with poor general conditions and surgical loadability, taking into account the rules of the profession. This solution still has a much higher morbidity factor for general and septic complications $[23,24]$.

\section{Results obtained from denaturation of synovial samples with different severity}

The denaturation curves of the SF samples can be seen in Fig. 2 at different stages of arthritis. The most characteristic change during the progress of disease is the significant increase in the half width $\left(T_{1 / 2}\right.$, the temperature interval of transition temperature at half of the heat flow in case of its maximum at $T_{\mathrm{m}}$ ) of the scans. In case of Gr.I., Gr.II., as well as Gr.III., it is the sign of the loosening of the cooperativity of the possible thermal domains of the sample, that is, in the different severity stages the structure became less ordered (see Table 2). The similar trend in the variation in calorimetric enthalpy supports further this statement.

The proteins play an important role in the SF from the point of view of thermal denaturation. The total protein content in normal SF varies between 9 and $22 \mathrm{~g} \mathrm{~L}^{-1}$, in non-inflammatory case it is about $32 \mathrm{~g} \mathrm{~L}^{-1}$, while in inflammatory case it rises up to $44 \mathrm{~g} \mathrm{~L}^{-1}$. The

Table 2 Distribution of bacteria isolated during articular infection between January 2012 and December 2016 at PTE, traumatology, and hand surgery clinic

\begin{tabular}{|c|c|c|c|c|c|c|c|}
\hline Bacterial strains & Hip joint & Knee joint & Ankle joint & $\begin{array}{l}\text { Shoulder } \\
\text { joint }\end{array}$ & Elbow joint & $\begin{array}{l}\text { Foot small } \\
\text { joint }\end{array}$ & $\begin{array}{l}\text { Hand } \\
\text { small } \\
\text { joint }\end{array}$ \\
\hline Staphylococcus aureus & 8 & 12 & 0 & 2 & 1 & 4 & 16 \\
\hline MRSA & 2 & 1 & 0 & 0 & 1 & 0 & 0 \\
\hline Staphylococcus epidermidis & 2 & 0 & 0 & 0 & 0 & 1 & 0 \\
\hline Staphylococcus coagulase negative & 12 & 4 & 1 & 1 & 0 & 0 & 3 \\
\hline Streptococcus pyogenes & 0 & 2 & 0 & 0 & 0 & 2 & 5 \\
\hline Streptococcus Alfa-hemolyticus & 0 & 1 & 1 & 0 & 0 & 1 & 13 \\
\hline Streptococcus Beta-hemolyticus & 0 & 0 & 0 & 0 & 0 & 1 & 0 \\
\hline Streptococcus $G$ & 1 & 0 & 0 & 0 & 0 & 0 & 0 \\
\hline Peptostreptococcus sp. & 1 & 0 & 0 & 0 & 0 & 0 & 2 \\
\hline Streptococcus agalactiae & 2 & 0 & 0 & 0 & 0 & 0 & 2 \\
\hline Streptococcus oralis & 0 & 0 & 0 & 0 & 0 & 1 & 1 \\
\hline Streptococcus pneumoniae & 0 & 1 & 0 & 0 & 0 & 0 & 0 \\
\hline Streptococcus anginosus & 2 & 1 & 0 & 0 & 0 & 0 & 0 \\
\hline Corynebacterium & 0 & 0 & 0 & 0 & 0 & 0 & 1 \\
\hline Acinetobacter baumannii & 2 & 0 & 0 & 0 & 0 & 0 & 0 \\
\hline Pseudomonas aeruginosa & 8 & 2 & 0 & 0 & 0 & 2 & 0 \\
\hline E. coli & 2 & 0 & 0 & 0 & 0 & 0 & 2 \\
\hline E. hemolyticus & 0 & 0 & 0 & 0 & 0 & 0 & 1 \\
\hline Bacteroides sp. & 0 & 0 & 0 & 0 & 0 & 0 & 1 \\
\hline Enterococcus sp. & 10 & 0 & 0 & 0 & 0 & 1 & 2 \\
\hline Enterobacter sp. & 2 & 0 & 0 & 1 & 0 & 3 & 5 \\
\hline Klebsiella pneumoniae & 0 & 0 & 0 & 1 & 0 & 0 & 1 \\
\hline Klebsiella oxytoca & 0 & 0 & 0 & 0 & 0 & 0 & 2 \\
\hline Hemophilus influenza & 0 & 0 & 0 & 0 & 0 & 0 & 1 \\
\hline Morganella morganii & 0 & 0 & 0 & 0 & 0 & 1 & 0 \\
\hline Cumulative positive result & 54 & 24 & 2 & 5 & 2 & 17 & 58 \\
\hline Primary negative result & 1 & 3 & 0 & 3 & 0 & 0 & 23 \\
\hline
\end{tabular}


most decisive compound albumin is about $60 \%$ of total $\left(\sim 11 \mathrm{~g} \mathrm{~L}^{-1}\right)$, and the others are different globulins, phospholipids, hyaluronic acid, and proteoglycan [25-27]. The DSC scans of different arthritic stages of SF (see Fig. 2) show a big similarity to the human blood plasma denaturation curves [28-34]. On the basis of the relative abundance of each component, it can be expected that the major transitions in the DSC curves would represent primarily the denaturation of the polypeptides [35]. We have decomposed the DSC scans of SF [36] using the data for melting temperatures of blood plasma from the literature [30-34], assuming similarity on the basis of composition with SF. $T_{\mathrm{m}} s \sim 50{ }^{\circ} \mathrm{C}$ was assigned to fibrinogen, $\sim 62{ }^{\circ} \mathrm{C}$ to albumin, $\sim 70{ }^{\circ} \mathrm{C}$ to immunoglobulins $(\mathrm{Ig}), \sim 76{ }^{\circ} \mathrm{C}$ to protein $\mathrm{C} 3, \operatorname{Ig} \mathrm{A}, \mathrm{IgG}$, and albumin's minor, while $\sim 82{ }^{\circ} \mathrm{C}$ significantly to $\operatorname{IgG}$ and transferrin. The fitting was relatively good (better than 99\%), but only three big transitions were dominant [36], similarly to Briere et al. [37]. Repeating the deconvolution of SF by the same way for severity Gr. 0-Gr. IV., we got also a good fitting which was more informative for the main compounds of SF (see Fig. 3 and Table 3).
Table 3 Thermodynamic parameters of denaturation of SF (presented according to the modified Kellgren-Lawrence classification [22])

\begin{tabular}{llll}
\hline $\begin{array}{l}\text { Degree of sever- } \\
\text { ity }\end{array}$ & $T_{\mathrm{m}} /{ }^{\circ} \mathrm{C}$ & $T_{1 / 2} /{ }^{\circ} \mathrm{C}$ & $\Delta H_{\text {cal }} / \mathrm{J} \mathrm{g}^{-1}$ \\
\hline 0. & 63.4 & 4 & 0.46 \\
I. & 64.3 & 11.5 & 0.32 \\
II. & $63.7 \pm 0.6$ & $12.4 \pm 0.4$ & $0.54 \pm 0.06$ \\
III. & 63.5 & 10.9 & 0.58 \\
IV. & $64.2 \pm 0.7$ & $8.2 \pm 0.3$ & $0.4 \pm 0.05$ \\
\hline
\end{tabular}

Data are average, and s.d. refers for those cases where the number of samples was more than five

\section{Results obtained from denaturation of infected synovial samples}

Figure 4 shows the infection increased the melting temperature $\left(T_{\mathrm{m}}\right)$. The calorimetric enthalpy change $\left(\Delta H_{\text {cal }}\right)$ and $T_{\mathrm{m}}$ increased in a ranking Staphylococci $>$ Streptococci $>$ Enterococci manner (see Table 4). It is the sign that the infected samples have different sensitivities for the different strains, and after the infection the structure becomes more "rigid" from thermal point of view compared with the control SF.
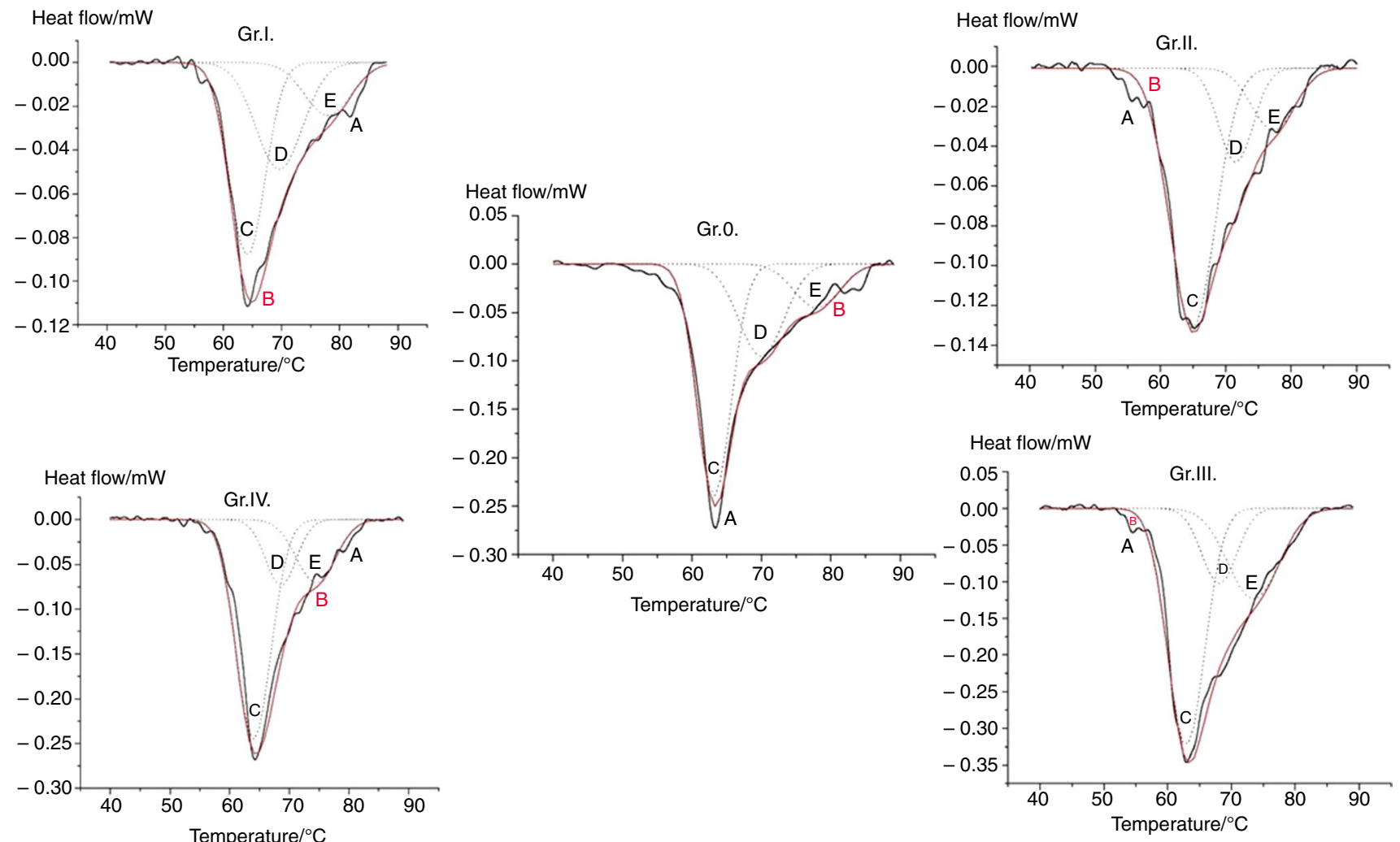

Fig. 3 Deconvoluted DSC scans of SF with different severities (Gr.0Gr.IV.). Symbols in figures are: $\mathrm{A}=$ experimental average curve, $\mathrm{B}=$ sum of the individual transitions (both are solid lines), and the dotted C-D-E curves stand for the main contributors of denaturation (C-albumin, $\mathrm{D} \alpha_{1}-\alpha_{2}, \beta$, and $\mathrm{E}$ to $\gamma$ globulins [37]). Endothermic deflection downwards 


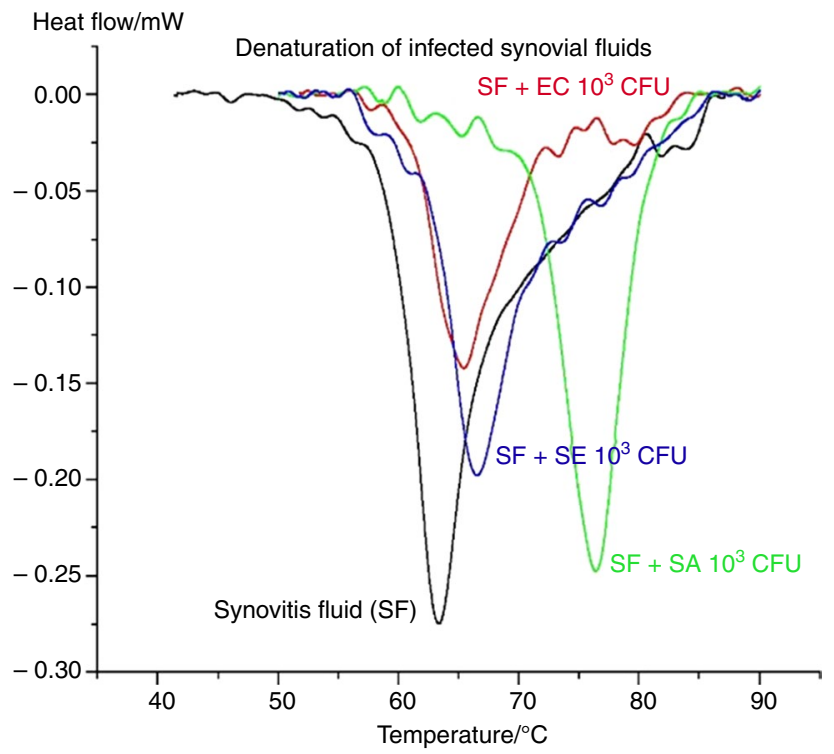

Fig. 4 Thermal denaturation of infected synovial fluids (endothermic directed downwards)

We have performed the deconvolution of infected DSC scans too, similarly as in case of different severities of disease (see Fig. 5).

Figure 5 and the thermal parameters in Table 5 show that the biggest damage rank in case of this infection is Staphylococcus aureus $>$ Staphylococcus epidermidis $>$ Escherichia coli, that is the albumin underwent (as a biggest compound of SF) to a severe structural change in this order.

\section{Results of isoperibol calorimetric measurements of the growth of bacterial strains}

The measurements were taken as it is described in part Investigation of bacterial strains with isoperibol calorimeter. The investigated strains were: Staphylococcus aureus ATCC 29213, MRSA (methicillin-resistant Staphylococcus aureus) \#4262 (\# means that it was isolated from a pyogenic clinical sample), Staphylococcus epidermidis ATCC 14990, Streptococcus pyogenes NCCP 11610, Escherichia coli ATCC 25922, and Pseudomonas aeruginosa ATCC 27853, with colony-forming units (CFU) $10^{3}$ or $10^{5}$ colonies $\mathrm{mL}^{-1}$ broth. The summarized proliferation curves can be seen in Fig. $6\left(\mathrm{CFU}=10^{3}\right)$ and Fig. $7\left(\mathrm{CFU}=10^{5}\right)$.

The scans clearly demonstrate the dependence of proliferation from the concentration (CFU) and type of bacteria. To follow the time dependence of the proliferation kinetics, we have deconvoluted the average curves according to Briere [37]. The maximum time and relative abundance of the possible proliferation phases can be found in Table 6 for infection with $\mathrm{CFU}=10^{3}$.

In case of Escherichia coli and Staphylococcus epidermidis bacteria, we have found three well separable phases. In both cases, the highest proliferation rate was in the last step. Staphylococcus aureus proliferation contained practically one step. The other bacteria exhibited four or five separable proliferation phases. It seems that the most active phase will appear around/above $7-8 \mathrm{~h}$ after the inoculation, which may be important from the point of view of treatment for the recognition and identification of the infection.

The proliferation is more complex infecting with $\mathrm{CFU}$ $10^{5}$. Its details can be read out from Table 7. In general, the highest rate was between 5 and $8 \mathrm{~h}$, but Staphylococcus epidermidis and Streptococcus pyogenes bacteria produced at the beginning and the close to the end of experiments proliferation rates around $10 \%$ of total enthalpy (see Table 7).

We have checked the effect of CFU with the maximum proliferation heat production too, which can be seen in Table 8 [24].

\section{Discussion}

In view of the severity of the damage to the body due to bacterial infection, in every case, in clinical practice, special care has to be taken to provide professional care to those who turn to a medical doctor with suspected joint infection.

Our retrospective study shows that as the number of highdegenerative lesions increases, the number of implanted hip and knee joint prostheses increases exponentially from year to year [38]. Wear and loosening of hip joint prostheses implanted several years/decades ago, and an increasing trend of Girdlestone status, which has been permanently
Table 4 Temperature midpoint $\left(T_{\mathrm{m}}\right)$ values of the three overlapping transitions (made by deconvolution) and relative contribution of each transition to the total enthalpy, observed in the average DSC scans of different synovial fluids with altering degree of severity

\begin{tabular}{|c|c|c|c|c|c|c|}
\hline Sample & $T_{\mathrm{mC}} /{ }^{\circ} \mathrm{C}$ & $\begin{array}{l}\text { Relative abun- } \\
\text { dance/\% }\end{array}$ & $T_{\mathrm{mD}} /{ }^{\circ} \mathrm{C}$ & $\begin{array}{l}\text { Relative abun- } \\
\text { dance } / \%\end{array}$ & $T_{\mathrm{mE}} /{ }^{\circ} \mathrm{C}$ & $\begin{array}{l}\text { Relative } \\
\text { abun- } \\
\text { dance/\% }\end{array}$ \\
\hline Gr.0. & 63.2 & 56.3 & 70 & 29.4 & 78 & 14.3 \\
\hline Gr.I. & 64.1 & 47.9 & 69.6 & 34.8 & 78 & 17.3 \\
\hline Gr.II. & 64.9 & 65.9 & 71.55 & 18.2 & 77.3 & 15.9 \\
\hline Gr.III. & 62.9 & 54.9 & 68.1 & 16.2 & 73.5 & 28.9 \\
\hline Gr.IV. & 64 & 63.1 & 68.6 & 16.4 & 74.5 & 20.5 \\
\hline
\end{tabular}


Fig. 5 Deconvoluted DSC curves of infected SF. The symbols and their meaning are the same as in the case in Fig. 3
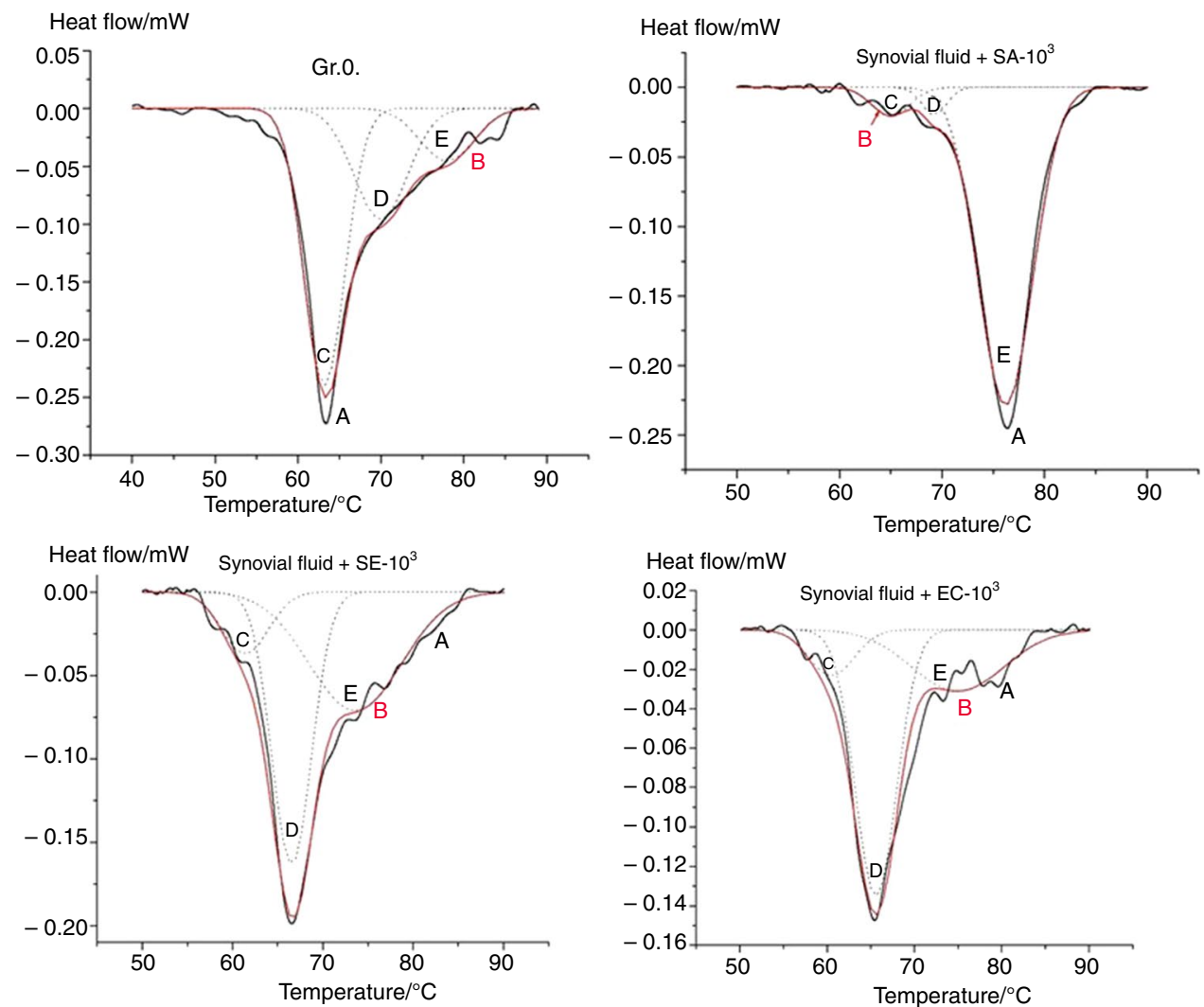

Table 5 Denaturation parameters of SF after inoculation with different bacteria

\begin{tabular}{lll}
\hline Samples & $T_{\mathrm{m}} /{ }^{\circ} \mathrm{C}$ & $\Delta H_{\text {cal }} / \mathrm{J} \mathrm{g}^{-1}$ \\
\hline Healthy synovial fluid (SF) & 63.4 & 0.46 \\
$\mathrm{SF}+$ Escherichia c. CFU $10^{5}$ & 65.3 & 0.54 \\
$\mathrm{SF}+$ Staphylococcus e. CFU $10^{3}$ & 65.7 & 0.56 \\
$\mathrm{SF}+$ Staphylococcus a. CFU $10^{3}$ & 76.4 & 0.6 \\
\hline
\end{tabular}

$T_{\mathrm{m}}$ stands for maximum temperature of denaturation, and $\Delta H_{\mathrm{cal}}$ for calorimetric enthalpy change, normalized for the sample mass [because of a few sample (less than 5), and there was no performed statistical evaluation (s.e.)]

abandoned as a result of septic hip joint periprosthetic necrosis, has been increasing year after year. Based on our survey, we can say that the large-joint prosthesis after elective nodule research has a much lower complication rate and a chance of septic infection. However, in the USA and the UK, the prevalence of septic complications is $12-15 \%$ after the hip replacement and $23-25 \%$ after knee revision, the cost of which is several times higher than that of the primary complication of large-joint prosthesis [23-25].

Infection with prosthesis revision, beyond the patient's burden, significantly increases hospital costs. In the case of a French study, the hospital costs of periprosthetic purulence during prosthesis revision are in the order of 32,000 Euros, which is 2.6 times more than the revision cost and 3.6 times

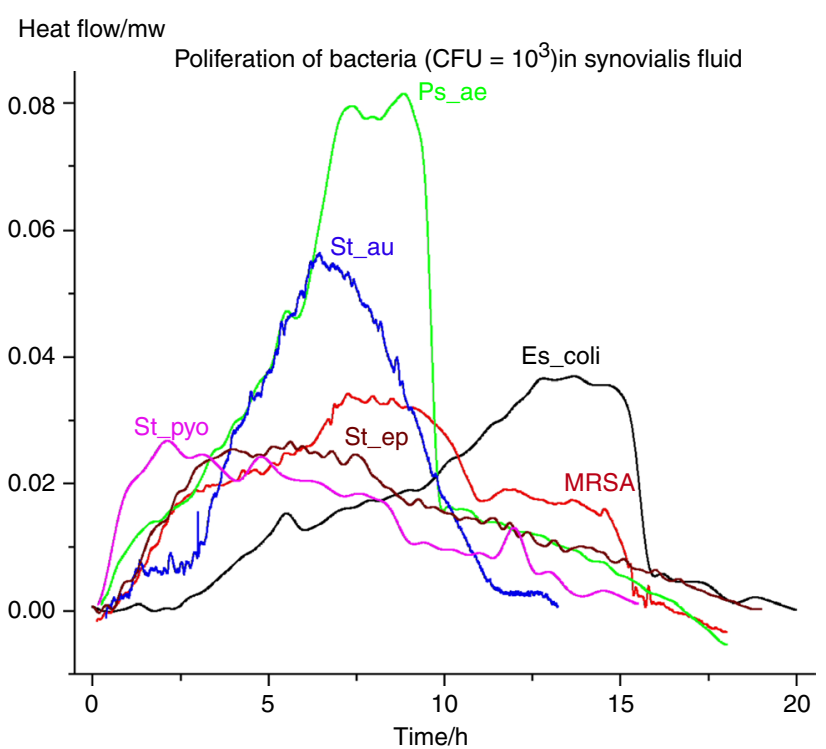

Fig. 6 Proliferation of Es._coli (Escherichia coli), MRSA, Ps._ae. (Pseudomonas aeruginosa), St._au. (Staphylococcus aureus), St._ep. (Staphylococcus epidermidis), as well as St._pyo. (Streptococcus pyogenes) bacteria ( $\mathrm{CFU}=10^{3}$, the curves are averages)

more expensive than the original primary prosthesis [26]. There is an urgent need to manage the periprosthetic infections and to quickly determine the use of the still effective antibiotic therapy available to us, backed by statistical data. 


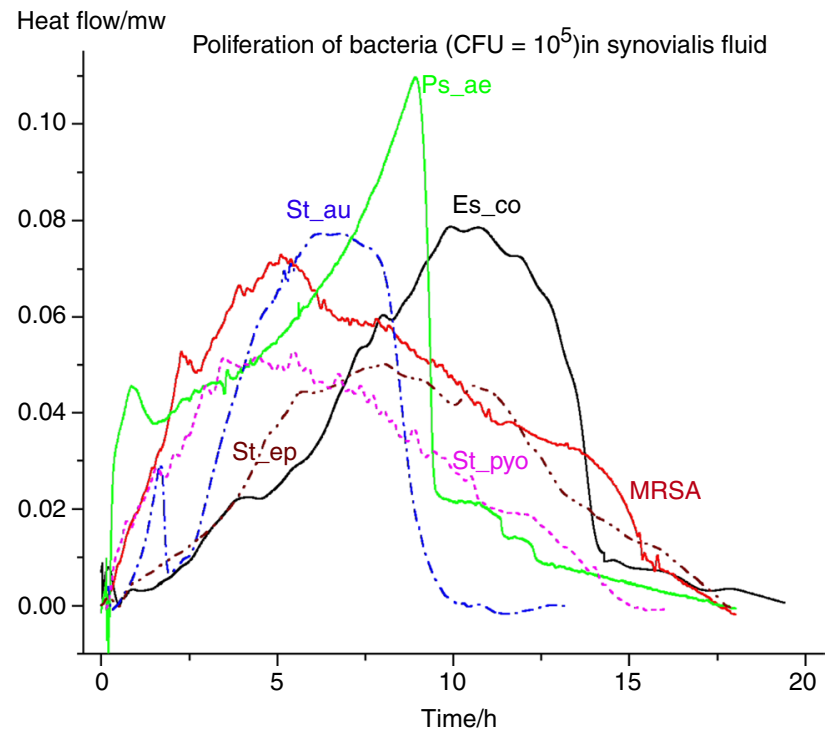

Fig. 7 Proliferation of the same bacteria with $\mathrm{CFU}=10^{5}$

According to our study [38], Gram-positive Staphylococcus aureus is the most common pathogen in knee and hip prosthetic complications, which is also supported by the literature $[33,34]$. In terms of its economic aspect, the incidence of methicillin-resistant Staphylococcus aureus (MRSA) and other multiresistant strains in the Staphylococcus infections is marked by a significant increase in the cost of care, which puts a greater economic burden on the healthcare system.
According to a recent study, D-dimer monitoring of serum for periprosthetic joint infection (PJI) is a sign of the disease. It is more effective than an erythrocyte sedimentation rate (ESR) or serum C-reactive protein (CRP) tests with its $89 \%$ sensitivity and specificity of $93 \%$ [35] (an additional option that the procalcitonin (PCT) is more sensitive than CRP in isolation of septic arthritis [39]). In addition to the monitoring of general inflammatory laboratory parameters (CRP, WBC, ESR, PCT), monitoring of serum D-dimer values after cost-effective screening, more expensive but also more sensitive and specific biomarkers as well as MALDITOF mass spectrometry can provide the fast and reliable results for pathogen isolation than a microbiological proliferation of bacteria [40-42].

Taking into account previous studies in case of suspected diagnosis of septic or periprosthetic infection, it may be advantageous-due to the shorter duration-a DSC [20,23] or the isoperibolic calorimeter compared to conventional microbiological cultures for the purpose of rapid diagnosis and choice of targeted antibiotic therapy [26, 24, 43-47]. Using DSC, we found that changes of thermal characteristics of human synovial fluid samples collected of patients with different grades of osteoarthritis have shown correlation with severity of arthritis [23]. However, it is important to note that the increasing tendency of calorimetric enthalpy after Grade I to Grade III osteoarthritis turned into a marked decrease in case of Grade IV samples (see Fig. 2 and Table 3). It can be explained by the fact that the severe sclerosis and definite bony deformity at this stage of osteoarthritis, accompanied
Table 6 Temperature midpoint $\left(T_{\mathrm{m}}\right)$ values of the three overlapping transitions (made by deconvolution) and relative contribution of each transition to the total enthalpy, observed in the average DSC scans of different infected synovial fluids $(\mathrm{SF}=$ synovial fluid, $\mathrm{SA}=$ Staphylococcus aureus, $\mathrm{SE}=$ Staphylococcus epidermidis, $\mathrm{EC}=$ Escherichia coli, and, e.g., $10^{3}$ stands for number of CFU.)

\begin{tabular}{|c|c|c|c|c|c|c|}
\hline Sample & $T_{\mathrm{mC}} /{ }^{\circ} \mathrm{C}$ & Relative abundance/\% & $T_{\mathrm{mD}} /{ }^{\circ} \mathrm{C}$ & Relative abundance/\% & $T_{\mathrm{mE}} /{ }^{\circ} \mathrm{C}$ & $\begin{array}{l}\text { Relative } \\
\text { abun- } \\
\text { dance/\% }\end{array}$ \\
\hline Gr.0. & 63.2 & 56.3 & 70 & 29.4 & 78 & 14.3 \\
\hline $\mathrm{SF}+\mathrm{SA} 10^{3}$ & 65 & 5.7 & 69.25 & 3.5 & 76.2 & 90.8 \\
\hline $\mathrm{SF}+\mathrm{SE} 10^{3}$ & 61.4 & 11.7 & 66.55 & 43.8 & 73.6 & 44.5 \\
\hline $\mathrm{SF}+\mathrm{EC} 10^{5}$ & 60.5 & 11 & 65.6 & 59.4 & 75 & 29.6 \\
\hline
\end{tabular}

Bold refers to the significant difference compared with Gr.0

Table 7 Proliferation time maxima $\left(t_{\mathrm{m}} s\right)$ and relative abundance (in $\%$, rounded to one decimal) in the total enthalpy of the deconvoluted curves (higher than 5\%) in case of those bacteria (see Materials) that make the most frequent infections $\left(\mathrm{CFU}=10^{3}\right)$

\begin{tabular}{lclllllll}
\hline Sample & $t_{\mathrm{m} 1} / \mathrm{h}$ & $\begin{array}{l}\text { Relative } \\
\text { abundance/\% }\end{array}$ & $t_{\mathrm{m} 2} / \mathrm{h}$ & $\begin{array}{l}\text { Relative } \\
\text { abundance/\% }\end{array}$ & $t_{\mathrm{m} 3} / \mathrm{h}$ & $\begin{array}{l}\text { Relative } \\
\text { abundance/\% }\end{array}$ & $t_{\mathrm{m} 4} / \mathrm{h}$ & $\begin{array}{l}\text { Relative } \\
\text { abun- } \\
\text { dance/\% }\end{array}$ \\
\hline E. coli & 5.6 & 17.7 & 9.1 & 26.8 & 13.4 & 66.7 & & \\
MRSA & 3.5 & 24.1 & 7.7 & 38.6 & 11.6 & 34.4 & & \\
Ps. aer. & 3.3 & 14.1 & 5.5 & 8.8 & 8 & 49.7 & 13.7 & 12.1 \\
St. aer. & & & 6.8 & 94.3 & & & & \\
St. epid. & 2.2 & 17.4 & 5.8 & 29.4 & 10.5 & 53.2 & & \\
St. pyo. & 2 & 31.7 & 4.9 & 27.6 & 7.6 & 24 & 11 & 13.8 \\
\hline
\end{tabular}


Table 8 Proliferation time maxima $\left(t_{\mathrm{m}} s\right)$ and relative abundance (in $\%$, rounded to one decimal) in the total enthalpy of the deconvoluted curves (higher than 5\%) in case of those bacteria that make the most frequent infections $\left(\mathrm{CFU}=10^{5}\right)$

\begin{tabular}{llllllllc}
\hline Sample & $t_{\mathrm{m} 1} / \mathrm{h}$ & $\begin{array}{l}\text { Relative } \\
\text { abundance/\% }\end{array}$ & $t_{\mathrm{m} 2} / \mathrm{h}$ & $\begin{array}{l}\text { Relative } \\
\text { abundance/\% }\end{array}$ & $t_{\mathrm{m} 3} / \mathrm{h}$ & $\begin{array}{l}\text { Relative } \\
\text { abundance/\% }\end{array}$ & $t_{\mathrm{m} 4} / \mathrm{h}$ & $\begin{array}{l}\text { Relative } \\
\text { abun- } \\
\text { dance/\% }\end{array}$ \\
\hline E. coli & 4.3 & 13 & 8.6 & 42.8 & 11.7 & 37.9 & 14.6 & 6.3 \\
MRSA & 2.4 & 9.8 & 5.1 & 38.6 & 11.6 & 34.4 & & \\
Ps. aer. & 3.3 & 14.1 & 5.5 & 40.3 & 8.6 & 20.2 & 12.3 & 27.4 \\
St. aer. & 4.6 & 37.9 & 6.4 & 25.9 & 7.8 & 30.3 & & \\
St. epid. & 3.5 & 8.1 & 5.7 & 21.1 & 8 & 23.1 & 10.8 & 33.3 \\
& & & & & & & 13.7 & 7.1 \\
St. pyo. & 1.3 & 9 & 5 & 27.6 & 7.5 & 15.1 & 12.5 & 10.6 \\
& 3.2 & 12.1 & & & 9.5 & 32.9 & & \\
\hline
\end{tabular}

Table 9 Thermal proliferation characteristics of bacteria causing frequent joint infections $\left(t_{\mathrm{o}}=\right.$ onset, $t_{\mathrm{e}}=$ end point and $t_{\mathrm{m}}=$ time maximum of proliferation rate, $\Delta H_{\text {cal }}=$ calorimetric enthalpy of proliferation [negative sign stands for exothermic process], data are averages, $n<5$, without s.d.). The maximum heat flow time and the calorimetric enthalpy are bacteria-dependent parameters

\begin{tabular}{|c|c|c|c|c|}
\hline \multirow{2}{*}{$\begin{array}{l}\text { Tested bacte- } \\
\text { rial strains }\end{array}$} & \multicolumn{4}{|c|}{ Thermal parameters } \\
\hline & $t_{\mathrm{o}}$ & $t_{\mathrm{e}}$ & $t_{\mathrm{m}}$ & $\Delta H_{\mathrm{cal}} / \mathrm{J} \mathrm{g}^{-1}$ \\
\hline \multicolumn{5}{|c|}{ Staphylococcus aureus } \\
\hline CFU $10^{3}$ & $26 \min$ & 13 h 22 min & $6 \mathrm{~h} 27 \mathrm{~min}$ & -1.48 \\
\hline CFU $10^{5}$ & $13 \mathrm{~min}$ & $13 \mathrm{~h} 30 \mathrm{~min}$ & $7 \mathrm{~h}$ & -1.98 \\
\hline \multicolumn{5}{|c|}{ Streptococcus pyogenes } \\
\hline CFU $10^{3}$ & $10 \mathrm{~min}$ & 15 h 30 min & $2 \mathrm{~h}$ & -0.64 \\
\hline CFU $10^{5}$ & $12 \mathrm{~min}$ & $15 \mathrm{~h} 50 \mathrm{~min}$ & $5 \mathrm{~h} 30 \mathrm{~min}$ & -2.45 \\
\hline \multicolumn{5}{|l|}{ MRSA } \\
\hline $\mathrm{CFU} 10^{3}$ & $15 \mathrm{~min}$ & $18 \mathrm{~h}$ & $7 \mathrm{~h} 16 \mathrm{~min}$ & -0.91 \\
\hline $\mathrm{CFU} 10^{5}$ & $8 \mathrm{~min}$ & $18 \mathrm{~h}$ & $5 \mathrm{~h} 5 \mathrm{~min}$ & -3.67 \\
\hline \multicolumn{5}{|c|}{ Pseudomonas aeruginosa } \\
\hline CFU $10^{3}$ & $16 \mathrm{~min}$ & $18 \mathrm{~h}$ & $8 \mathrm{~h} 50 \mathrm{~min}$ & -2.48 \\
\hline $\mathrm{CFU} 10^{5}$ & $16 \mathrm{~min}$ & 17 h 50 min & $9 \mathrm{~h}$ & -3.32 \\
\hline \multicolumn{5}{|c|}{ Staphylococcus epidermidis } \\
\hline CFU $10^{3}$ & $8 \mathrm{~min}$ & $19 \mathrm{~h}$ & $5 \mathrm{~h} 37 \mathrm{~min}$ & -0.66 \\
\hline CFU $10^{5}$ & $10 \mathrm{~min}$ & 17 h 50 min & $8 \mathrm{~h} 20 \mathrm{~min}$ & -1.58 \\
\hline \multicolumn{5}{|c|}{ Escherichia coli } \\
\hline CFU $10^{3}$ & $8 \min$ & $20 \mathrm{~h}$ & $13 \mathrm{~h}$ & -1.56 \\
\hline CFU $10^{5}$ & $9 \min$ & 19 h 35 min & $9 \mathrm{~h} 55 \mathrm{~min}$ & -3.22 \\
\hline
\end{tabular}

with the altered bone turnover and importantly, the final stage in synovial degeneration, will result in a different cellular distribution and synovial fluid contents, compared to the previous stages. The improved data evaluation based on [37] (see Fig. 3 and Table 4) clarified that the biggest effect of arthritis is made on albumin compound of synovial fluid.

Those denatured infected samples where the synovial fluids underwent to a whole day bacterial proliferation after inoculation showed that the most aggressive bacterium is Staphylococcus aureus with the highest denaturation temperature and calorimetric enthalpy (see Fig. 4 and Table 5).
After deconvolution of this average scan (see Fig. 5 and Table 6), we have observed that practically $90 \%$ of the denaturation shifted from around $63{ }^{\circ} \mathrm{C}$ up to $76{ }^{\circ} \mathrm{C}$, showing that the basic plasma compounds made a common strong aggregation during this infection.

Recently, the isoperibolic technique seems to be a quick test for the identification of different bacteria [40-41]. Figures 6 and 7 show the proliferation rate after inoculation. Pseudomonas aeruginosa exhibited the highest heat rate and reached the maximum rate together with Staphylococcus aureus and MRSA. On the basis of Figs. 6 and 7 as well as Tables 7 and 8, it can be seen that the proliferation has multistep characteristics. In case of $\mathrm{CFU}=10^{3}$, the most aggressive Staphylococcus aureus reached about $94 \%$ relative abundance with maximum heat rate at $7 \mathrm{~h}$, while at $10^{5}$ starting bacterium concentration most of the bacteria exhibited higher than $10 \%$ relative abundance (decompositions less than 5\% are not presented in the table). The summarized thermal parameters of proliferation (see Table 9) show that the time of maximum of heat rate can be a good parameter for the identification of bacteria.

\section{Conclusions}

Based on the literature data and our measurements, we can conclude that in the case of septic high-joint infection, traditional diagnostic methods based on parameters that can be determined from the blood and synovial fluid are not sufficient. Using the data from our clinical study, prosthesis implantations and prosthesis revisions due to hip fracture and periprosthetic fracture have a significantly higher septic complication rate in our investigated patient group. Worldwide, there is an increase in the number of high-joint primary prosthetic prostheses. Because of the increase in the number of prosthetic revisions after the primary prosthetic prostheses as well as the increased prosthetic revisions caused by periprosthetic fractures, we should wait for increased chances of septic complication. Based on our 
performed clinical study, the sensitivity of the previously assured microbiological inoculation in case of joint and periprosthetic infection is low, which may affect the effectiveness of the nodule examination prior to implantation of the elective prosthesis. In the possession of the data, it can be stated that only conventional microbiological sampling is not sufficient to identify the pathogenic agent. In the clinical practice, in addition to routinely used serum laboratory tests (CRP, WBC, ESR, PCT, D-dimer) and very rarely used and costly other analytical procedures, the DSC and isoperibol calorimetry can be a quick, sensitive, and cost-effective alternative. A calorimetric test is more cost-effective in the diagnosis of bacterial infections, as well as in the study of antibiotic susceptibility of isolated bacterial strains, than the well-known special biomarkers, and MALDI-TOF Mass Spectrometric analyses. It is time-consuming, compared with other testing methods, only a few hours [41].

Acknowledgements Open access funding provided by University of Pécs (PTE). This work was supported by Grant OTKA CO-272 (for D. Lôrinczy).

Open Access This article is licensed under a Creative Commons Attribution 4.0 International License, which permits use, sharing, adaptation, distribution and reproduction in any medium or format, as long as you give appropriate credit to the original author(s) and the source, provide a link to the Creative Commons licence, and indicate if changes were made. The images or other third party material in this article are included in the article's Creative Commons licence, unless indicated otherwise in a credit line to the material. If material is not included in the article's Creative Commons licence and your intended use is not permitted by statutory regulation or exceeds the permitted use, you will need to obtain permission directly from the copyright holder. To view a copy of this licence, visit http://creativecommons.org/licenses/by/4.0/.

\section{References}

1. Barber M. Meticillin-resistant staphylococci. J Clin Pathol. 1961;14:385-93.

2. Resch H, Breitfuss H. Spontaneous tendon ruptures. Etiology, pathogenesis and therapy. Orthopade. 1995;24:209-19.

3. Miles CA, Burjanadze TV, Bailey AJ. The kinetics of the thermal denaturation of collagen in unrestrained rat tail tendon determined by differential scanning calorimetry. J Mol Biol. 1995;245:437-46.

4. Charlson ME, Allegrante JP. Disparities in the use of total joint arthroplasty. N Engl J Med. 2000;342:1044-5.

5. Gazsó I, Kránicz J, Bellyei Á, Lőrinczy D. DSC analysis of the abnormalities of human leg skeletal muscles: a preliminary study. Thermochim Acta. 2003;402:117-22.

6. Comerford EJ, Innes JF, Tarlton JF, Bailey AJ. Investigation of the composition, turnover, and thermal properties of ruptured cranial cruciate ligaments of dogs. Am J Vet Res. 2004;65:1136-41.

7. Amlang MH, Zwipp H. Damage to large tendons: achilles, patellar and quadriceps tendons. Chirurg. 2006;77:637-49 (quiz 649).

8. Bognár G, Szabó I, Bálint L, Hepp B, Kereskai L, Lőrinczy D. Thermal effects of shoulder electrothermal arthroscopic capsulorrhaphy monitored by differential scanning calorimetry-a preliminary study. Thermochim Acta. 2007;464:78-82.

9. Willett TL, Labow RS, Lee JM. Mechanical overload decreases the thermal stability of collagen in an in vitro tensile overload tendon model. J Orthop Res. 2008;26:1605-10.

10. Clayton RA, Court-Brown CM. The epidemiology of musculoskeletal tendinous and ligamentous injuries. Injury. 2008;39:1338-44.

11. Wiegand N, Vámhidy L, Patczai B, Dömse E, Than P, Kereskai L, Lőrinczy D. Differential scanning calorimetric examination of transverse carpal ligament in carpal tunnel disease. J Therm Anal Calorim. 2009;95:793-6.

12. Wiegand N, Vámhidy L, Patczai B, Dömse E, Than P, Kereskai L, Lőrinczy D. Differential scanning calorimetric examination of the degenerated human palmar aponeurosis in dupuytren disease. J Therm Anal Calorim. 2009;95:797-800.

13. Wiegand N, Vámhidy L, Patczai B, Dömse E, Kereskai L, Lőrinczy D. Differential scanning calorimetric examination of the human skeletal muscle in a compartment syndrome of the lower extremities. J Therm Anal Calorim. 2009;98:177-82.

14. Wiegand N, Vámhidy L, Lőrinczy D. Differential scanning calorimetric examination of ruptured lower limb tendons in human. $\mathbf{J}$ Therm Anal Calorim. 2010;101:487-92.

15. Naumov I, Lőrinczy D, Vámhidy L, et al. Differential scanning calorimetric examination of the human hyaline cartilage of the femoral head after femoral neck fracture. J Therm Anal Calorim. 2012;108:59-65.

16. Naumov I, Lőrinczy D, Vámhidy L, et al. Differential scanning calorimetric examination of the interfacial membrane in failed hip joint replacements. J Therm Anal Calorim. 2012;109:783-7.

17. Wiegand N, Naumov I, Nöt LG, et al. Differential scanning calorimetric examination of pathologic scar tissues of human skin. J Therm Anal Calorim. 2013;111:1897-902.

18. Nöt LG, Naumov I, Vámhidy L, et al. Comparison of thermal characteristics of degenerated and inflamed human collagen structures with differential scanning calorimetry. J Therm Anal Calorim. 2013;113:273-9.

19. Shirtliff ME, Mader JT. Acute septic arthritis. Clin Microbiol Rev. 2002;15(4):527-44.

20. Sillinger T, Lőrinczy D, Kocsis B, Kereskay L, Nőt LG, Wiegand N. Differential scanning calorimetric measurement of cartilage destruction caused by gram-negative septic arthritis. J Therm Anal Calorim. 2014;116:747-52.

21. Rice PA. Gonococcal arthritis (disseminated gonococcal infection). Infect Dis Clin North Am. 2005;19(4):853-61.

22. Kellgren JH, Lawrence JS. Radiological assessment of osteoarthrosis. Ann Rheum Dis. 1957;16:494-502.

23. Dandé Á, Nőt LG, Wiegand N, Kocsis B, Lơrinczy D. DSC analysis of human synovial fluid samples in the diagnostics of non-septic and septic arthritis. J Therm Anal Calorim. 2017;130:1249-52.

24. Dandé Á, Nőt LG, Búcs G, Wiegand N, Kocsis B, Lőrinczy D. Examination of typical bacterial strains in septic arthritis by isoperibol calorimeter. J Therm Anal Calorim. 2018;131(3):2041-8.

25. Oates KM, et al. Rheopexy of synovial fluid and protein aggregation. J R Soc Interface. 2006;3(6):167-74.

26. Blewis ME, et al. A model of synovial fluid lubricant composition in normal and injured joints. Eur Cell Mater. 2007;13:26-39.

27. Mazzucco D, Scott R, Spector M. Composition of joint fluid in patients undergoing total knee replacement and revision arthroplasty: correlation with flow properties. Biomaterials. 2004;25(18):4433-45.

28. Michnik A, Michalik K, Kluczewska A, Drzazga Z. Comparative DSC study of human and bovine serum albumin. J Therm Anal Calorim. 2006;84:113-7. 
29. Garbett NC, Miller JJ, Jenson AB, Miller DM, Chaires JB. Interrogation of the plasma proteome with differential scanning calorimetry. Clin Chem. 2007;53(11):2012-4.

30. Garbett NC, Mekmaysy C, Helm CV, Jenson AB, Chaires JB. Differential scanning calorimetry of blood plasma for clinical diagnosis and monitoring. Exp Mol Pathol. 2009;86(3):186-91.

31. Todinova S, Krumova S, Gartcheva L, Robeerts C, Taneva SG. Microcalorimetry of blood serum proteome: a modified interaction network in the multiple myeloma case. Anal Chem. 2011;83:792-8.

32. Zapf I, Fekecs T, Ferencz A, Tizedes Gy, Pavlovics G, Kálmán E, Lőrinczy D. DSC analysis of human plasma in breast cancer patients. Thermochimica Acta. 2011;524:88-91.

33. Fekecs T, Zapf I, Ferencz A, Lőrinczy D. DSC analysis of human plasma in melanoma patients with or without regional lymph node metastases. J Therm Anal Calorim. 2012;108:149-52.

34. Todinova S, Krumova S, Kurtev P, Dimitrov V, Djongov L, Dudunkov Z, Taneva SG. Calorimetry-based profiling of blood plasma from colorectal cancer patients. Biochim Biophys Acta. 2012;1820:1879-85.

35. Lepock JR. Measurement of protein stability and protein denaturation in cells using differential scanning calorimetry. Methods. 2005;35(2):117-25.

36. Wiegand N, Búcs G, Dandé Á, Lőrinczy D. Investigation of protein content of synovial fluids with DSC in different arthritis. J Therm Anal Calorim. 2019. https://doi.org/10.1007/s10973-01908151-6.

37. Briere L-AK, Brandt JM, Medley JB. Measurement of protein denaturation in human synovial fluid and its analogs using differential scanning calorimetry. J Therm Anal Calorim. 2010;102:99-106.

38. Dandé Á. Diagnostic possibility of septic arthritis diagnosis examining human synovial samples by DSC. PhD Thesis in Hungarian, Medical school of University Pécs, 2019

39. Zhao J, Zhang S, Zhang, L, Dong X, Li J, Wang Y, Van Y. Serum procalcitonin levels as a diagnostic marker for septic arthritis: a meta-analysis. Am J Emerg Med 2017;35:1166-71.

40. Hidron A, Edwards J, Patel J, Horan T, Sievert D, Pollock D, Fridkin S. Antimicrobial-Resistant pathogens associated with healthcare-associated infections: annual summary of data reported to the national healthcare safety network at the centres for disease control and prevention, 2006-2007. Inf Control Hosp Epidem 2008;29(11):996-1011.

41. Portillo ME, Salvado M, Sorli L, Alier A, Martinez, S, Trampuz A, Gomez J, Puig L, Horcajada JP. Multiplex PCR of sonication fluid accurately differentiates between prosthetic joint infection and aseptic failure. J Infect 2012;65(6):541-8.

42. Portillo ME, Corvec S, Borens O, Trampuz A. Propionibacterium acnes: an underestimated pathogen in implant-associated infections. BioMed Res Int 2013. https://doi.org/10.1155/2013/80439 1 .

43. Schäffer B, Daróczi L, Keller B, Szakály Z, Lőrinczy D. Examination of proliferation of probiotic microbes by isoperibolic calorimetry. J Therm Anal Calorim 2013;111:1891-6.

44. Baldoni D, Hermann H, Frei R, Trampuz A, Steinhuber A. Performance of microcalorimetry for early detection of methicillin resistance in clinical isolates of Staphylococcus aureus. J Clin Microbiol 2009;47(3):774-776.

45. Yusuf E, Hugle T, Daikeler T, Voide C, Borens O, Trampuz A. The potential use of microcalorimetry in rapid differentiation between septic arthritis and other causes of arthritis. Eur J Clin Microbial Inf Dis 2015;34(3):461-5.

46. Braissant O, Muller G, Egli A, Widmer A, Frei R, Halla A, Wirz D, Gasser TC, Bachmann A, Wagenlehner F, Bonkat G. Seven hours to adequate antimicrobial therapy in urosepsis using isothermal microcalorimetry. J Clin Microbiol 2014;52(2):624-6.

47. Trampuz A, Salzmann S, Antheaume J, Daniels AU. Microcalorimetry: a novel method for detection of microbial contamination in platelet products. Transfusion. 2007;47(9):1643-50.

Publisher's Note Springer Nature remains neutral with regard to jurisdictional claims in published maps and institutional affiliations. 